\title{
A Multi-Level Conceptualization of Empathy to Explain How Diversity Increases Group Performance
}

\author{
Marie-Élène Roberge ${ }^{1}$ \\ ${ }^{1}$ Northeastern Illinois University, USA \\ Correspondence: Marie-Élène Roberge, 5500, N. Saint Louis Avenue, Chicago, IL, 60625, USA. Tel: \\ 1-773-442-6137. E-mail: m-roberge@neiu.edu
}

Received: October 9, 2012

Accepted: November 29, 2012 Online Published: January 21, 2013

doi:10.5539/ijbm.v8n3p122

URL: http://dx.doi.org/10.5539/ijbm.v8n3p122

\begin{abstract}
This paper focuses on affective empathy and the role it plays in explaining how diversity may increase group performance in organizations. It suggests that both individual-level empathy and group-level empathy are key mechanisms that explain how people in diverse groups may work harmoniously together and increase the overall group performance. Finally, the paper addresses the theoretical and practical implications of a multi-level conceptualization of empathy and it provides recommendations for future research.
\end{abstract}

Keywords: diversity, emotions, empathy, performance

\section{Introduction}

Diversity is a concept that has brought lots of attention in the literature for the last twenty years. Diversity refers to differences between individuals on any attributes (i.e., demographic characteristics, informational/functional characteristics, personality traits, personal values, religious beliefs, sexual orientation, or mental and physical health and abilities) that may lead to the perception that another person is different from the self (Jackson, 1992; van Dick, Van Knippenberg, Hägele, Guillaume, \& Brodbeck, 2008; Triandis, Kurowski, \& Gelfand, 1994; van Knippenberg, De Dreu, \& Homan, 2004; Williams \& O’Reilly, 1998). Mostly, research has attempted to explain how diversity increases group performance by focusing on cognitive processes such as social identity and self-categorization theories (Turner, Hogg, Oakes, Reicher, \& Wetherell, 1987; Tajfel, 1978). However, recently some researchers have tried to shift the literature toward an understanding of how diversity increases group performance that focuses on emotional processes. In particular, researchers have identifies affective empathy as an important mechanism that explains how diversity increase group performance (Ensari \& Miller, 2006; Roberge \& van Dick, 2010; Stegmann, Roberge, \& van Dick, 2012).

Researchers have identify affective empathy as an important emotional mechanism that helps individuals to relate to others by understanding each other, which then reduce stereotyping and the likelihood of behaving in a discriminatory manner toward different others (Batson, Polycarpou, Harmon-Jones, Imhoff, Mitchener, Bednar, Klein, \& Highberger, 1997; Galinsky \& Moskowitz, 2000). We further examine this perspective by developing a multi-level conceptualization of empathy. We suggest that both individual-level empathy and group-level empathy are necessary mechanisms to explain how people in diverse groups may work harmoniously together and increase the overall group performance.

The paper aims to make a contribution to the literature by recognizing the role that affective empathy plays in explaining the relationship between diversity and group performance. Empathy has been studied by psychologists since the 1920s and even before (Batson, 1991, 2010; Davis, 1994; Duan \& Hill, 1996; Dovidio, Johnson, Gaertner, Pearson, Saguy, \& Ashburn-Nardo, 2010). Few recent studies from the field of organizational behavior have shown that empathy, as a trait affect, is associated with organizational citizenship behavior (Kamdar, McAllister, \& Turban, 2006; Settoon \& Mossholder, 2002). However, it is only recently that researchers from the field of organizational behavior have begun examining the effects of empathy, as a state affect, and the role it plays in diverse environments (Roberge, 2009). It is indeed surprising to realize that very few scholars have studied the role of affective empathy in resolving workplace conflicts and diversity related issues such as sexual harassment or any other forms of discrimination (see Reiter-Palmon, Wiener, Ashley, Winter, Smith, Richter, \& Voss-Humke, 2008). Thus, by focusing on the mediating effects of empathy between diversity and group performance, we intend to extend the diversity literature by adding a new perspective to the 
field of organizational behavior. As pointed out by Shore, Chung-Herrera, Dean, Ehrhart, Jung, Randel, and Singh (2009), "we [researchers] need to change our originating paradigms which are primarily negative, emphasizing discrimination and victimization, to explore diversity from a more positive and proactive standpoint” (p. 127). The paper is an initiative to adopt a more positive approach toward diversity research by analyzing the role that an emotional component, affective empathy, plays in explaining the relationship between diversity and group performance. Mainly, the paper contributes to the literature by exploring two conceptual levels of empathy: 1. Empathy as an individual-level mechanism, and 2. Empathy as a group-level mechanism. The paper emphasizes the functionality of individual empathy in reducing stereotyping and discriminatory behaviors toward different others. It also describes the necessity of experiencing group empathy to assure that diversity can reveal its full potential and thus increase group performance. Finally, but not the least, the paper contributes to the development of theory-building in the field of organizational behavior, and more specifically in the field of workplace diversity. Until today, most research studies have limited their understanding of the relationship between diversity and group performance by focusing exclusively on a cognitive process: The social categorization process (see Van Knippenberg, De Dreu, \& Homan, 2004). By emphasizing and explaining the importance of affective empathy, as an emotional process, the paper contributes to broaden our theoretical understanding of how diversity may increase group performance.

In the following sections, the literature on diversity is first briefly reviewed and the current theory that explains the relationship between diversity and group performance are discussed. Then, a model (see figure 1) that proposes a multi-level conceptualization of affective empathy (at an individual-level and a group-level) to explain the relationship between diversity and group performance is presented. The paper addresses the effects of each conceptual level of empathy in diverse organizations. Finally, it addresses the theoretical and practical implications of a multi-level conceptualization of empathy to explain how diversity can increase group performance, and we propose some recommendations for future research.

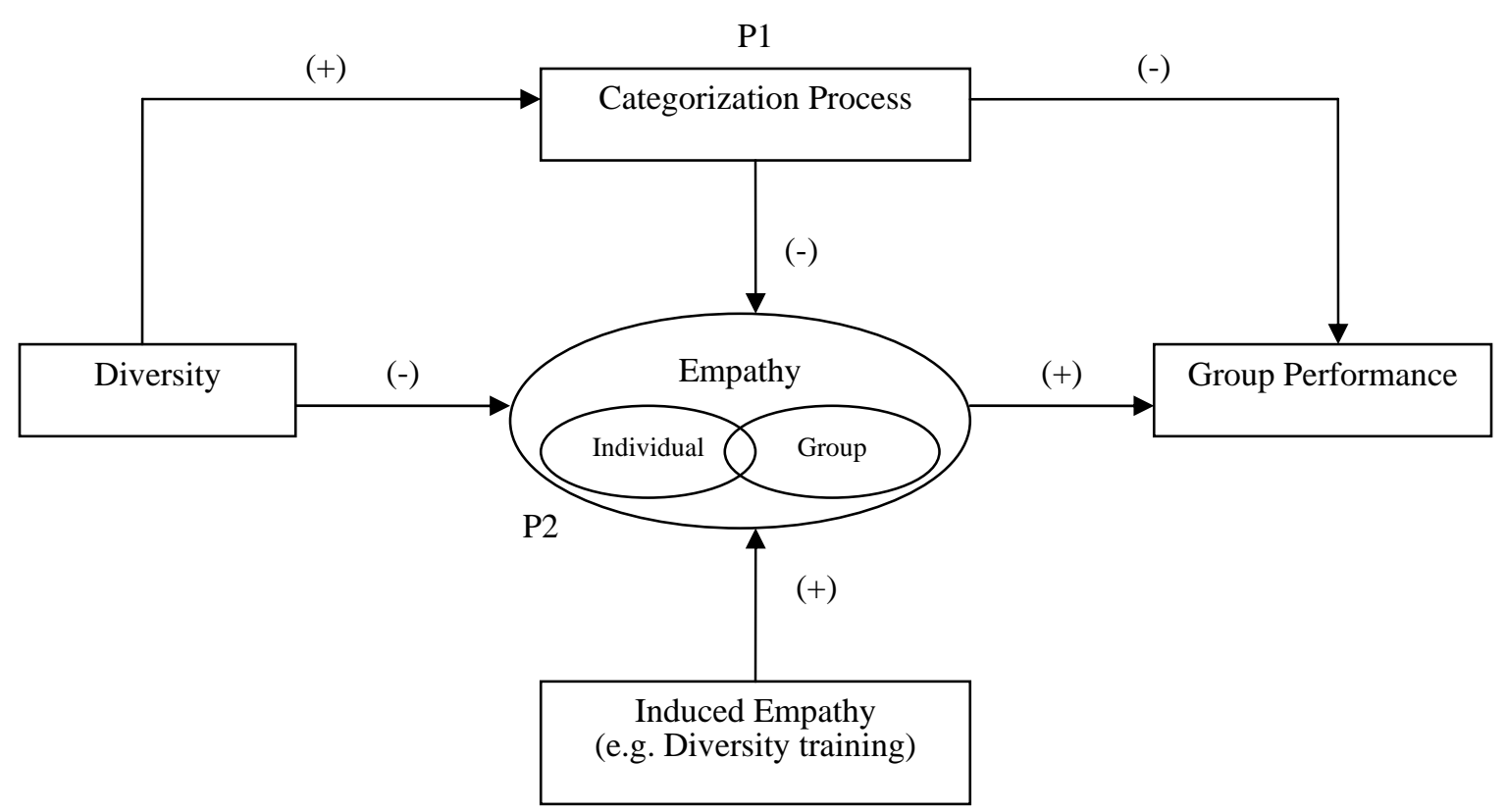

Figure 1. Multi-Level conceptualization of empathy and its effects between diversity and group performance

\section{How does Diversity Increases or Decreases Group Performance?}

Literature reviews (Van Knippenberg, \& Schippers, 2007; Shore, et al., 2009; Williams and O’Reilly, 1998) as well as meta-analyses (Bowers, Pharmer, \& Salas, 2000; Webber \& Donahue, 2001) have found no consistent main effects of diversity on group performance. A limited amount of studies have provided supportive evidence that diversity yields increased group performance. Those studies which do support such an optimistic prediction have examined informational-related dimensions such as education, occupation or functional background (Jehn, Northcraft, \& Neal, 1999; Pelled, Eisenhardt, \& Xin, 1999; Wanous \& Youtz, 1986). Among studies that 
examine demographic indicators (e. g., gender, age, ethnicity, personality, values or attitudes), very few of these have demonstrated that diversity may indeed lead to positive consequences (Bantel, \& Jackson, 1989; Barrick, Stewart, Neubert, \& Mount, 1998; Barry, \& Stewart, 1997; Joshi, Liao, \& Jackson, 2006; Kristof-Brown, Barrick, \& Stevens, 2005; McLeod, Lobel, \& Cox, 1996).

\subsection{Social Identity Theory and Self-Categorization Theory}

To explain how diversity may decrease or possibly increase group performance, the majority of the research has drawn upon self-categorization theory (Turner et al. 1987), and social identity theory (Tajfel, 1978). These theories propose that people working in diverse groups are likely to perceive differences between themselves and others, and because of the activation of social categorization process in diverse environments, people are likely to categorize themselves and others into different social categories and assume that themselves and others belong to different social identities. By cognitively categorizing themselves and others in different social categories, people working in diverse groups are less likely to collaborate with others than people working in similar groups. Thus, the theories suggest that people use perceived similarities and differences as a basis for categorizing self and others, and to decide to collaborate or not with others. Moreover, the theories suggest that the activation of social-categorization process may disrupt elaboration of task-relevant information because of positive biases (e.g. favoritisms) toward in-group members and negative biases toward out-group members (e.g. derogation). Overall, research drawing on social identity theory and self-categorization theory suggests that because diverse group settings are more likely to activate the effects of social-categorization processes, diversity is negatively related to empathy, social interaction and communication, and it is positively related to conflict and misunderstanding which decrease group performance (Williams \& O’Really, 1998). As a result, proposition 1 is as follow:

Proposition 1: Diversity is positively related to social categorization process which is negatively related to empathy and group performance.

Recent research supports that the activation of social categorization process depends on the way the diversity attributes are distributed within the group also called "faultline". Research suggests that when multiple attributes of diversity converge within the group, a strong faultline occurs, which increases the salience of differences between subgroups, resulting in more intra group conflicts, a reduction in the quality of communication and a deterioration of group functioning across those subgroups (Lau \& Maurnighan, 2005).

Social identity theory and self-categorization theory propose that reducing the salience of ingroup-outgroup distinctions is a key condition to explain how diversity may lead to positive effects (Brewer \& Gaertner, 2004). More precisely, research has proposed that sharing a common ingroup identity or stressing out any other communalities (i.e., sharing the same values, goals, beliefs, opinions, affects or behaviors), by restructuring or redefining group boundaries at a higher level of category inclusiveness (also called a superordinate category), may reduce the negative consequences of diversity (Allport, 1954). Specifically, the common ingroup identity model (Gaertner \& Dovidio, 2000; Gaertner, Dovidio, Anastasio, Bachman, \& Rust, 1993; Gaertner, Dovidio, Nier, Ward, \& Banker, 1999; Gaertner, Dovidio, Rust, Nier, Banker, Ward, Mottola, \& Houlette, 1999) proposes that intergroup biases can be reduced by transforming people' representations of group memberships from two groups to one, more inclusive group (Brewer \& Gaertner, 2004). By redefining group boundaries into a superordinate level category, group members are likely to categorize themselves as well as others under the same category and as a result they are more likely to collaborate with each other despite their existing differences. Thus, social identity theory and self-categorization theory suggest that emphasizing a common identity among diverse group members is a key to increase the likelihood of positive outcomes (Brewer, \& Brown, 1998; Brewer \& Gaertner, 2004). By sharing identities, people working in diverse groups are more likely to identify themselves to each other and, as a result, to empathize, collaborate and thus increase group performance.

Thus, social-categorization process has been the main psychological process identified and considered by the organizational behavior literature to explain how diversity may impact group performance (see van Knippenberg et al., 2004). In this paper, we want to shift researchers' attention from the previous literature, which focuses only on cognitive processes, to emphasize the role that emotional processes plays in explaining the relationship between diversity and group performance.

\section{3. "Feeling Empathy” to Explain the Relationship between Diversity and Group Performance}

Recently, diversity researchers have begun identifying other types of psychological mechanisms that may explain how diversity increases group performance such as empathy (Ensari \& Miller, 2006; Roberge \& van Dick, 2010; Stegmann, Roberge, \& van Dick, 2012). Empathy has been defined either from a cognitive or 
emotional perspective. Cognitive empathy refers to knowing how the other person feels and what that person might be thinking (REF). However, the present paper deviates from previous research by focusing on affective empathy which has been defined as "a state of emotional arousal that stems from the apprehension or comprehension of another's affective state" (Losoya \& Eisenberg, 2001, p. 22). Affective empathy refers to "feeling for", which implies feeling for a person or a group of people by being concern for that person or that group. Affective empathy has often been referred as "empathic concern" (Batson, 2010). In the following sections, the word empathy will be used to refer only to affective empathy.

Feeling empathy for someone refers to the extent to which one's feeling is congruent with other's feeling; Feeling positively when the other's state is positive, or feeling negative when the other's state is negative. However, it is important to stress that affective empathy does not imply feeling similarity or emotional convergence, which refers to two (or more) people coming to feel more similarly (Anderson, Keltner \& John, 2003). As pointed out by Batson and Ahmad (2009), "You might, for example, feel sad or sorry for someone who is scared and upset" (p. 146). Empathy is about "feeling for" someone and not about "feeling as" someone. Researchers from the field of organizational behavior have mostly studied "feeling as" or feeling similarity instead of studying "feeling for". Research from social psychology suggests that it is "feeling for" someone that has direct effects on prosocial behavior and not "feeling as". Moreover, research suggests that "feeling as" is neither a necessary not it is a sufficient precondition for "feeling for" someone (Batson, Early, \& Salvarani, 1997; Batson \& Ahmad, 2009).

Moreover, despite the fact that most studies from social psychology have examined empathy as a negative state affects (i.e., "I feel for your pain"), empathy can also refer to positive state affects (i.e., "I am happy for you"). Empathy can be experienced by individuals and it can also be experienced collectively by a group of people who mutually share the feeling of empathy for one another. The literature from social psychology has mostly examined the individual-level of empathy (Batson, 2010). In this paper, we contribute to enlarge our understanding of empathy by discussing its group-level of analysis and its importance in explaining how diversity can increase group performance.

The reasons why it is important to carefully examine the role that affective empathy plays in diverse organizations is because research suggests that when empathy is induced it evokes altruistic motivation and therefore it can produce a motivational counterbalance to the egoistic desires that may be activated by social categorization process in diverse groups (Batson, 1991, 2010; Hoffman, 2000). Research shows that induced empathy increases people's concerns for the welfare of a different other and the group as a whole (Batson, Polycarpou, Harmon-Jones, Imhoff, Mitchener, Bednar, Klein, \& Highberger, 1997). Empathy makes it difficult for people to use derogation as a means of maintaining belief in a just world. Empathy increases moral judgment and helps people to better resolve conflicts between individuals or between people belonging to different groups or having different identities (Gibbs, 2003). As mentioned by Batson et al. (1997) "it [empathy] should encourage prosocial action to remove the injustice instead" (p. 106). Empathy is the mean through which people understand one another's feelings and experience and bound emotionally with others. Empathy is an emotional psychological mechanism that leads to increase the likelihood of activating other psychological mechanisms such as self-disclosure (Phillips, Rothbard, \& Dumas, 2009), mutual identity confirmation (Milton \& Westphal, 2005), and team learning behaviors (Gibson \& Vermeulen, 2003; van der Vegt \& Bundeson, 2005). The feeling of being emotionally understood by others may indeed lead people to open up themselves and disclose valuable information which would otherwise not be shared. Without empathy, how can people learn from one another and engage in mutual identity confirmation? How can the group, as a whole, learn if this emotional understanding among group members does not exist? Empathy is a functional and a crucial mechanism that must be taken into account in order to be able to predict the activation of any other positive psychological mechanisms, at an individual-, dyadic- or group-levels, that explain how diversity may increase group performance.

Finally, another reason why considering empathy in organizations is crucial is because people's empathy level toward specific social groups shapes their views of organizational policies that affect the welfare of others. For example, as pointed out by Batson and Ahmad (2009), having empathy toward different minority groups may influence willingness to support affirmative action programs (Harrisson, Kravitz, Mayer, Leslie, \& Lev-Arey, 2006). For examples, having empathy for people living with disabilities may influence support for accommodating their needs in organizations. Knowing that the implementation of diversity practices has become increasingly popular among today’s organizations (Roberge, Lewicki, Hietapelto, \& Abdyldaeva, 2011), it is very important to assure that the implementation of diversity practices may be perceived by employers as a positive and not a negative long term commitment. Research suggests that by inducing empathy, through 
training programs, for example, it might be possible to increase workers' support toward different types of diversity practices and policies in organizations. Such a possibility will be further explored in the discussion section.

In this paper, it is argued that in order to uncover the mediating effects that empathy has between diversity and group performance, researchers must conceptualize empathy as an individual- and a group-level mechanism. Empathy is not only an emotional response that may be reduced by the activation of the categorization process, but instead it is conceptualized as an individual level and a group level phenomena, that are underlying mechanisms and that when activated or induced can improve performance of diverse groups. More specifically we proposed as follow:

Proposition 2: Empathy has mediating moderated effects between diversity and group performance in such as way that when empathy is induced, via diversity training program for example, empathy at both levels (i.e., individual and group) positively mediates the relationship between diversity and group performance.

See Figure 1, it illustrates the proposed multi-level conceptualization of empathy and its mediating moderated effects between diversity and group performance.

\subsection{Empathy as an Individual-Level Mechanism}

Empathy as an individual-level mechanism helps people to relate to others by reducing stereotyping and the likelihood of behaving in a discriminatory manner toward different others. Empirical studies have provided evidence that empathy is an important individual psychological mechanism that may also help to explain how diversity lead to positive rather than negative consequences. For example, studies (Batson, Polycarpou, Harmon-Jones, Imhoff, Mitchener, Bednar, Klein, \& Highberger, 1997; Batson, Chang, Orr, \& Rowland, 2002) suggest that having empathy for a member of a stigmatized group (people with HIV/AIDS, homeless people, a convicted murderers or drug dealers) can improve individual' attitudes toward the group as a whole by reducing stereotyping and increasing helping behavior.

Similarly, Galinsky and Moskowitz's (2000) studies found that when individuals take another's perspective, which relate to cognitive empathy instead of affective empathy, they are more likely to feel for others and become more accurate in understanding the feelings of others. Galinsky and Moskowitz' studies suggest that perspective-taking can be a useful strategy for inducing affective empathy, decreasing stereotyping and increasing overlap between representations of the self and representations of the other. This self and other psychological merger, in turn, increases the likelihood of empathy and therefore the manifestation of prosocial behavior (Dovidio, Gaertner, Validzic, Motaka, Johnson \& Frazier, 1997).

Moreover, research suggests that the level of affective empathy experience toward different others may depend on people's identification toward group memberships. As proposed by social identity theory (Tajfel \& Turner, 1986) and self-categorization theory (Turner et al., 1987), in heterogeneous groups individuals are more likely to perceive themselves as belonging to different group memberships than others and thus, as a result, they are less likely to experience a high level of empathy for others, reducing the likelihood for prosocial behavior to occur. Because of the activation of the social categorization process in diverse group settings, affective empathy may be difficult to experience, and even if it is experienced, the level of affective empathy that people experience might be too low to lead to prosocial behavior. In order words, in diverse group settings, people may not be able to care enough for others to engage in prosocial behavior. A study conducted by Stürmer, Snyder, Kropp and Siem (2006) confirms that the strength of the empathy-(ingroup) helping relationship systematically varied as a function of perceived similarities or differences among ingroup members. This study suggests that due to perceived differences, the level of empathy experience by individuals may be reduced in diverse group settings, leading to a reduction of collaboration among group members and therefore a decrease in group performance.

\subsection{Empathy as a Group-Level Mechanism}

Several scholars have provided evidence that team members come to develop mutually shared moods and emotions in the course of executing their tasks (Anderson, Keltner \& John, 2003; Smith \& Crandell, 1984; Sandelands \& St. Clair, 1993; Barsade \& Gibson, 1998). In the organizational behavior literature, this phenomenon has been referred to as group affective tone which consists of consistent or homogenous affective reactions within a group (George, 1990, 1996; George, \& Bettenhausen, 1990). However, it is important to recognize that most of this stream of research is not about affective empathy but instead it is about affect similarity (Barsade, Ward, Turner, \& Sonnenfeld, 2000; Bartel, \& Saavedra, 2000). As discussed earlier, "feeling as" and "feeling for" are two different state affect. This paper moves forward from the previous literature by focusing on group empathy and not on affective group similarity. 
Group empathy also named collective empathy has almost never been studied before (Roberge, 2009). However, despite our limited scientific knowledge, intuitively, it is possible to believe that sharing empathy within a group of people may increase group performance. A high level of collective empathy would be experienced when people, within a group, all mutually agree that they feel for one another. Too often researchers have neglected to examine empathy as a group-level mechanism to explain how diverse groups may increase group performance. It is now time to recognize the importance of collective empathy in diverse environment as Milton and Westphal (2005) suggested: "mutual empathy should provide the basis for a high level of social cohesion and cooperation with others in the group" (p. 194). In accordance with this reasoning, the personalization model (Brewer \& Miller, 1984) suggests that it is through empathy that intergroup relations in organizations can improve, and thereby increase effectiveness and productivity (Ensari \& Miller, 2006). The bottom line is that empathy at both individual-level but especially group-level are crucial psychological mechanisms that increase group performance.

To measure collective empathy, let's be inspired by Druskat and Wolff's (2001a) work which describes a concept closely related to collective empathy called group emotional intelligence. Druskat and Wolff suggest that groups that experience a high level of emotional intelligence are able of confrontation and care for one another at the same time. Druskat and Wolff (2001a) suggest that when confrontation and caring are both the norms in place, it is possible to experience positively confrontation among group members. Druskat and Wolff (2001a) propose that caring might be done by "displaying positive regard, appreciation and respect for group members through behaviors such as support, validation, and compassion” (p.84). Those behaviors could be considered indicators of empathy although Druskat and Wolff (2001) do not explicitly refer to group empathy. Their norm of caring is similar to affective empathy at a group-level of analysis and therefore could be measured similarly.

Thus, collective empathy is a key mechanism that explains how diverse groups may increase group performance. However, it is important to emphasize that the positive mediating effects of group empathy may be due to either positive or negative feelings experienced by group members. Contradictory to research on group affective tone, this paper suggests that the valence of the shared emotions (i.e., negative or positive) does not matter as much as the process itself of sharing mutual empathetic feelings for one another at a group-level. It is by sharing mutual empathetic feelings that coworkers from diverse groups may become able to overcome conflicts and, as a result, may collaborate efficiently with others, which consequently increases group performance. The experience of sharing similar emotions at a group-level may facilitate interpersonal interactions and group functioning as pointed out by previous Organizational Behavior studies (Anderson, Keltner \& John, 2003; George, 1990; 1996). However, as it was mentioned before, it is not feeling similarity that has direct effect on collaboration and prosocial behaviors, but instead it is the process of sharing the feeling of mutually caring for one another. In other words, whatever the emotional valence the group is experiencing (positive or negative), the importance is on mutually caring for one another, at a group-level, in order for diverse people to become able to increase their group performance. When all group members mutually care and feel for one another, the group experience a high level of collective empathy which allows group members to be able to easily regulate negative emotions experienced during conflict or confrontation, which, consequently, increase the likelihood of showing proactive behavior toward one another and collaboration among one another (Druskat \& Wolff, 2001).

\section{Discussion}

\subsection{Theoretical Implications}

By focusing on a multi-level conceptualization of empathy to explain the relationship between diversity and group performance, the present paper has responded to Shore et al.'s, (2009) call for a shift in the paradigms guiding the diversity literature toward a more positive light and proactive standpoint. Until today, little is known about the role that empathy plays in diverse group settings (Roberge, 2009; Roberge \& Van Dick, 2010). Research from social psychology has already addressed empathy as an individual-level mechanism that explains how people help different others and develop more positive attitudes toward perceived outgroup members. However, group empathy has rarely been addressed and studied and thus the importance of sharing mutual empathy, at a group-level, in diverse group settings has never been thoroughly discussed before (Ensari \& Miller, 2006; Roberge \& van Dick, 2010).

By shedding light on the emotional processes that explain how diversity may increase group performance, this paper help to broaden our theoretical understanding of the relationship between diversity and group performance. However, from a theoretical stand point, this new shift in paradigm raises many important research questions that are until today unanswered. For example, can induced empathy in diverse organizations override the 
negative effects of social categorization process? Some research suggests that the effects of induced empathy may indeed take precedence over the effects of the social categorization process. Batson and Moran (1999), and Batson and Ahmad (2001), have tested this possibility by placing undergraduate women in a standard, simultaneous decision one-trial prisoner's dilemma, and interestingly they found significantly more cooperative responses among those who were induced to feel empathy for the competitor (the other woman) than among those who were not induced to feel empathy. These studies predicted this result based on the extensive evidence that affective empathy evokes altruistic motivation with the ultimate goal of increasing the welfare of the person for whom empathy is felt (see Batson, 1991; Batson \& Shaw, 1991, for reviews). Batson and his colleagues reasoned that in a one-trial prisoner's dilemma, a person who feels empathy for the other will experience altruistic motivation to increase the other's welfare and the effects of social categorization process will be cancelled out. In order words, this research suggests that the effects of induced affective empathy may take precedence over the effects of social categorization process in predicting cooperation with different others. Testing such hypothesis in diverse organizations reminds an endeavor for future research.

Furthermore, this paper stresses the necessity to develop and build theory about workplace diversity that takes into consideration both the cognitive and emotional processes to explain the relationship between diversity and group performance. Unfortunately, too often, researchers have forgotten the power of emotions, and in this case the power of individual and group empathy and their effects on people's decision to collaborate with different others. This is definitely a new direction for future theory about workplace diversity.

\subsection{Practical Implications}

Overall, the proposed multi-level conceptualization of empathy suggests that affective empathy is a crucial state affect that explain how diverse groups become able to increase their performance. Diverse organizations could emphasize the importance of empathy by implementing training programs that focus on inducing empathy among employees (Stephan \& Finlay, 1999). A number of studies have shown that it is possible to increase levels of empathy through a variety of training programs (Crabb, Moracco, \& Bender, 1983; Goldstein \& Michaels, 1985). For example, Erera (1997) found that training social work students in emotional empathy by having them imagine the emotional responses of their clients increase levels of empathy and successful intervention. Another study found that an empathy-oriented rape awareness training program that included discussions of historical cases increased empathy for victims of rape (Pinzone-Glover, Gidycz, \& Jacobs, 1998). Similarly, Pacala, Boult, Bland, and O'Brien (1995) found that training medical students in empathy for the elderly led to increased empathy and more favorable attitudes toward elderly individuals. This empirical evidence supports the importance of implementing training programs in diverse organizations that focus on increasing empathy among employees. The effects of such training programs may significantly improve interpersonal relations between diverse people and their overall group performance. However, such type of training has been neglected in organizations and therefore there are opportunities for researchers to bring a meaningful contribution by further investigating the applications of empathy in diversity training programs.

\subsection{Directions for Future Research}

First, research should examine the factors that can active or induce empathy at both an individual-level and a group-level. From an individual-level perspective, there might be important individual factors that have an impact on empathy level that should be explored. For example, research suggests that when diverse people believe in diversity, they are more likely to increase group performance (Van Dick et al., 2008). It would be interesting to know whether people who believe in diversity experience a higher level of empathy toward others than those people who do not believe in diversity. Also, other researchers propose that personality traits such as openness to experience and the need for cognitions moderate the relationship between diversity and group performance (Homan, Hollenbeck, Humphrey, van Knippenberg, Ilgen, \& van Kleef, 2008; Kearney, Gebert, \& Voelpel, 2009). Possibly, it would be interesting to know whethere open minded people and those who strive for cognitions are more empathetic. Such research questions must be addressed by future studies.

Moreover, the challenge for diversity researchers is not only to find out the factors that increase the likelihood for employees to empathize with different others, but it is especially to find out how to increase empathize level so that people care for different others enough to decide to collaborate with them and as a result to increase the group performance. As mention before, recent studies suggests that in diverse group settings, people may some how feel for others, but they may not care for different others enough to decide to collaborate with them (Stürmer, Snyder, Kropp \& Siem, 2006). Therefore, it is very important to know more about the working conditions that will help people to experience enough empathy and decide to collaborate with others. For example, the literature suggests that the organizational values may help to induced empathy at an individual- 
and a group-level. Consistently with this idea, Chatman and Spataro (2005) have demonstrated the that people with different demographic characteristics behave more cooperatively when their business unit emphasizes collectivistic values (i.e., benevolence, tradition, conformity) rather than individualistic values (i.e., power, achievement, hedonism, stimulation, self-direction). Collectivistic values are motivated by serving the interests of others and especially the group as a whole such as understanding, appreciating, and tolerating all people with no regard to their rank. Alternatively, individualistic values are motivated by self-interests, such as possessing social status and prestige, controlling, and dominating people and their resources, or being considered successful and demonstrating competences based on social standard (Schwartz, 1992). Based on the results found by Chatman and Spataro (2005), it is suggests that when organizational culture emphasizes collectivistic values and interchangeable interests (Chatman, Polzer, Barsade, \& Neale, 1998) as opposed to individualistic values, people are more likely to experience a higher level of empathy for others and as a group, people are more likely to share mutual empathy toward one another, as a result, collaboration among group members occur and group performance can increase. Such hypothesis should be tested by conducting future empirical studies.

Furthermore, implementing a pro-diversity climate may help to induce empathy (McKay, Avery, \& Morris, 2008). Gelfand, Nishii, Raver, and Schneider (2005) define a pro-diversity climate in organizations as "employees shared perceptions of the policies and practices that implicitly and explicitly communicate the extent to which fostering diversity and eliminating discrimination is a priority in the organization" (p.104). When such type of climate exists among group members, we believe that individuals are more likely to experience a high level of empathy toward different others, and to share mutual affective empathy toward one another. This again has never been empirically tested, only future research will be able to bring more insights into the working conditions that contribute to induce empathy at an individual- and a group-level.

\section{Conclusion}

This paper sheds light on the social psychological state of affective empathy which has been largely neglected by the Organizational Behavior literature until recently (Ensari \& Miller, 2006; Roberge \& van Dick, 2010). By drawing on social psychology studies, the paper discusses the role that affective empathy plays in explaining how workplace diversity may increase organizational performance. It defines empathy at an individual and a group level and argues that affective empathy experienced by diverse people mediates the relationship between diversity and group performance. The paper is an attempts to develop a theory that will take into consideration not only cognitive processes but also emotional processes to explain the relationship between diversity and group performance. Finally, the paper addresses the theoretical and practical implications of a multi-level conceptualization of empathy and it provides recommendations for future research in the field of diversity management.

\section{Acknowledgements}

Thank to Denise M. Rousseau, Daniel Batson, Rachel P. Kreiter, Sebastian Stegmann and Rolf van Dick for their comments on previous drafts of this paper.

\section{References}

Allport, G. H. (1954). The nature of prejudice. Cambridge, MA: Addision-Wesley.

Anderson, C., Keltner, D., \& John, O. P. (2003). Emotional convergence between people over time. Journal of Personality and Social Psychology, 84, 1054. http://dx.doi.org/10.1037/0022-3514.84.5.1054

Bantel, K., \& Jackson, S. (1989). Top management and innovations in banking: Does the composition of the team make a difference? Strategic Management Journal, 10, 107-124. http://dx.doi.org/10.1002/smj.4250100709

Barsade, S. G., \& Gibson, D. E. (1998). Group emotion: A view from top and bottom. Research on Managing Groups and Teams, 1, 81-102. Retrieved from http://www.donaldegibson.com/files/Group\%20Emotion.pdf

Barsade, S. G., Ward, A. J., Turner, J. D. F., \& Sonnenfeld, J. A. (2000). To your heart's content: A model of affective diversity in top management teams. Administrative Science Quarterly, 45, 802-836. http://dx.doi.org/10.2307/2667020

Barrick, M. R., Stewart, G. L., Neubert, M. J., \& Mount, M. K. (1998). Relating member ability and personality to work-team processes and team effectiveness. Journal of Applied Psychology, 83, 377-391. http://dx.doi.org/10.1037/0021-9010.83.3.377

Barry, B., \& Stewart, G. L. (1997). Composition, process, and performance in self-managed groups: The role of personality. Journal of Applied Psychology, 82, 62-78. http://dx.doi.org/10.1037/0021-9010.82.1.62 
Bartel, C. A., \& Saavedra, R. (2000). The collective construction of work group mood. Administrative Science Quarterly, 45, 197-231. http://dx.doi.org/10.2307/2667070

Batson, C. D. (1991). The Altruism Question: Toward a social-psychological answer. Erlbaum: Hillsdale, NJ.

Batson, C. D. (2010). Empathy-induced altruistic motivation. In Mario Mikulincer \& Phillip R. Shaver (Eds.), Prosocial motives, emotions, and behavior: The better angles of our nature (pp. 15-53). http://dx.doi.org/10.1037/12061-001

Batson, C. D., \& Ahmad, N. (2009). Using empathy to improve intergroup attitudes and relations. Social Issues and Policy Review, 3, 141-177. http://dx.doi.org/10.1111/j.1751-2409.2009.01013.x

Batson, C. D., \& Ahmad, N. (2001). Empathy-induced altruism in a prisoner's dilemma II: What if the target of empathy has defected? European Journal of Social Psychology, 31, 25-36. http://dx.doi.org/10.1002/ejsp.26

Batson, C. D., Chang, J., Orr, R., \& Rowland, J. (2002). Empathy, attitudes, and action: Can feeling for a member of a stigmatized group motivate one to help the group? Personality and Social Psychology Bulletin, 28, 1656-1666. http://dx.doi.org/10.1177/014616702237647

Batson, C. D., Early, S., \& Salvarani, G. (1997). Perspective taking: Imagining how another feels versus imagining how you would feel. Personality and Social Psychology Bulletin, 23, 751-758. http://dx.doi.org/10.1177/0146167297237008

Batson, C. D., \& Moran, T. (1999). Empathy-induced altruism in a Prisoner's Dilemma. European Journal of Social Psychology, 29, http://dx.doi.org/10.1002/(SICI)1099-0992(199911)29:7<909::AID-EJSP965>3.0.CO;2-L

Batson, C. D., Polycarpou, M. P., Harmon-Jones, E., Imhoff, H. J., Mitchener, E. C., Bednar, L. L., Klein, T. R., \& Highberger, L. (1997). Empathy and attitudes: Can feeling for a member of a stigmatized group improve feeling toward the group? Journal of Personality and Social Psychology, 72, 105-118. http://dx.doi.org/10.1037/0022-3514.72.1.105

Batson, C. D., \& Shaw, L. L. (1991). Evidence for altruism: Toward a pluralism of prosocial motives. Psychological Inquiry, 2, 107-122. http://dx.doi.org/10.1207/s15327965pli0202_1

Bowers, C. A., Pharmer, J. A., \& Salas, E. (2000). When member homogeneity is needed in work teams. A meta-analysis. Small Group Research, 31, 305-327. http://dx.doi.org/10.1177/104649640003100303

Branscombe, N. R., \& Doosje, B. (2004). Collective Guilt: International Perspective. Cambridge.

Brewer, M. B., \& Brown, R. J. (1998). Intergroup relations. In D. T. Gilbert, S. T. Fiske, G. Lindzey (Eds.), The Handbook of Social Psychology (Vol. 2, pp. 554-594). McGraw-Hill Companies, Inc.

Brewer, M. B., \& Gaertner, S. L. (2004). Toward reduction of prejudice intergroup contact and social categorization. In M. B. Brewer \& M. Hewstone (Eds.), Self and Social Identity (pp. 298-318). Malden, MA: Blackwell Publishing.

Chatman, J., Polzer, J., Barsade, S., \& Neale, M. (1998). Being different yet feeling similar: The influence of demographic composition and organizational culture on work processes and outcomes. Administrative Science Quarterly, 43, 749-780. http://dx.doi.org/10.2307/2393615

Chatman, J. A., \& Sparato, S. E. (2005). Using self-categorization theory to understand relational demography-based variations in peoples' responsiveness to organizational culture. Academy of Management Journal, 48, 321-331. http://dx.doi.org/10.5465/AMJ.2005.16928415

Crabb, W. T., Moracco, J. C., Bender, R. C. (1983). A comparative study of empathy training with programmed instruction for lay helpers. Journal of Counseling Psychology, 30, 221-226. http://dx.doi.org/10.1037/0022-0167.30.2.221

Davis, M. H. (1994). Empathy: A social psychological approach. Boulder, CO: Westview Press.

Dovidio, J. F., Gaertner, S. L., Validzic, A., Motaka, K., Johnson, B., \& Frazier, S. (1997). Extending the benefits of recategorization: Evaluations, self-disclosure, and helping. Journal of Experimental Social Psychology, 33, 401-420. http://dx.doi.org/10.1006/jesp.1997.1327

Dovidio, J. F., Johnson, J. D., Gaertner, S. L., Pearson, A. R., Saguy, T., \& Ashburn-Nardo, L. (2010). Empathy and intergroup relations. Prosocial motives, emotions, and behavior: The better angles of our nature (pp. 393-408). 
Druskat, V. U., \& Wolff, S. B. (2001a). Building the emotional intelligence of groups. Harvard Business Review, 79, 81-90. http://academy.clevelandclinic.org/Portals/40/HBRBuilding\%20EI\%20of\%20Team.pdf

Druska, V. U., \& Wolff, S. B. (2001b). Group emotional intelligence and its influence on group effectiveness. In C. Cherniss \& D. Goleman (Eds.), The Emotionally Intelligent Workplace (pp. 132-155).

Duan, C., \& Hill, C. E. (1996). The current state of empathy research. Journal of Counseling Psychology, 43, 261-274. http://dx.doi.org/10.1037/0022-0167.43.3.261

Ensari, N. K., \& Miller, N. (2006). The application of the personalization model in diversity management. Group Processes and Intergroup Relations, 9, 589-607. http://dx.doi.org/10.1177/1368430206067679

Erera, P. I. (1997). Empathy training for helping professionals: Model and evaluation. Journal of Social Work Education, 33, 245-260.

Gaertner, S. L., \& Dovidio, J. F. (Eds.) (2000). Reducing intergroup bias: The common ingroup identity model. Philadelphia: Psychology Press.

Gaertner, S. L., Dovidio, J. F., Anastasio, P. A., Bachman, B. A., \& Rust, M. C. (1993). The common ingroup identity model: Recategorization and the reduction of intergroup bias. In W. Stroebe and M. Hewstone (Eds.), European review of social psychology (Vol. 4, pp. 1-26). London: Wiley.

Gaertner, S. L., Dovidio, J. F., Nier, J. A., Ward, C. M., \& Banker, B. S. (1999). Across cultural divides: The value of a superordinate identity. In D. Prentice and D. Miller (Eds.), Cultural divides: Understanding and overcoming group conflict (pp. 173-212). New York: Russell Sage Foundation.

Gaertner, S. L., Dovidio, J. F., Rust, M. C., Nier, J. A., Banker, B., Ward, C. M., Mottola, G. R., \& Houlette, M. (1999). Reducing intergroup bias: Elements of intergroup cooperation. Journal of Personality and Social Psychology, 76, 388-402. http://dx.doi.org/10.1037/0022-3514.76.3.388

Galinsky, A. D., \& Moskowitz, G. B. (2000). Perspective-taking: Decreasing stereotype expression, stereotype accessibility, and in-group favoritism. Journal of Personality and Social Psychology, 78, 708-724. http://dx.doi.org/10.1037/0022-3514.78.4.708

Gelfand, M. J., Nishii, L. H., Raver, J., \& Schneider, B. (2005). Discrimination in organizations: An organizational level systems perspective. In R. Dipboye \& A Colella (Eds.), Discrimination at work: The psychological and organizational bases (pp. 89-116). Mahwah, NJ: Erlbaum.

George, J. M. (1990). Personality, affect, and behavior in groups. Journal of Applied Psychology, 75, 107-116. http://dx.doi.org/10.1037/0021-9010.75.2.107

George, J. M. (1996). Group affective tone. In M. West (Ed.), Handbook of work group psychology (pp. 77-93). New York: Wiley.

George, J. M., \& Bettenhausen, K. (1990). Understanding prosocial behavior, sales performance, and turnover: A group level analysis in a service context. Journal of Applied Psychology, 75, 698-709. http://dx.doi.org/10.1037/0021-9010.75.6.698

Gibbs, J. C. (2003). Moral Development and Reality: Beyond the Theory of Kohlberg and Hoffman. Sage Publications.

Gibson, C., \& Vermeulen, F. (2003). A healthy divide subgroups as a stimulus for team learning behavior. Administrative Science Quarterly, 48, 202-239. http://dx.doi.org/10.2307/3556657

Goldstein, A. P., \& Michaels, G. Y. (1985). Empathy: Development, training, and consequences. Hilldsale, NJ: Erlbaum.

Harrison, D. A., Kravitz, D. A., Mayer, D. M., Leslie, L. M., \& Lev-Arey, D. (2006). Understanding attitudes toward affirmative action programs in employment summary and meta-analysis of 35 years of research. Journal of Applied Psychology, 91, 1013-1036. http://dx.doi.org/10.1037/0021-9010.91.5.1013

Harrisson, D. A., \& Sin, H, P. (2005). What is diversity and how should it be measured? In A. M. Konrad, P. Prasad, and J. K. Pringle (Eds.), Handbook of workplace diversity (pp. 191-216). Newbury Park, CA: Sage.

Hoffman, M. L. (2000). Empathy and moral development: Implications for caring and justice. New York: Cambridge University Press. http://dx.doi.org/10.1017/CBO9780511805851

Homan, A. C., Hollenbeck, J. R., Humphrey, S., van Knippenberg, D., Ilgen, D. R., \& van Kleef, G. A. (2008). Facing differences with an open mind: Openness to experience, salience of intragroup differences, and performance of diverse work groups. Academy of Management Journal, 51, 1204-1222. 
http://dx.doi.org/10.5465/AMJ.2008.35732995

Jackson, S. E. (1992). Consequences of group composition for the interpersonal dynamics of strategic issue processing. Advances in Strategic Management, 8, 345-382. Retrieved from http://www.google.com/url?sa=t\&rct=j\&q=consequences\%20of\%20group\%20composition\%20for\%20the \%20interpersonal\%20dynamics\%20of\%20strategic\%20issue\%20processing.\%20advances\%20in\%20strate gic\%20management\%2C\%208\&source=web\&cd=1\&ved=0CCEQFjAA\&url=http\%3A\%2F\%2Fsmlr.rutge rs.edu\%2Fconsequences-of-group-composition-susan-jackson\&ei=e3u_UPmUE8Hw2QWJxoG4Cg\&usg= AFQjCNHUWa_HkQ7ehrOdyBXjjqkQ4Mf40Q

Jehn, K. A., Northcraft, G. B., \& Neale, M. A. (1999). Why differences make a difference: A field study of diversity, conflict, and performance in workgroups. Administrative Science Quarterly, 44, 741-763. http://dx.doi.org/10.2307/2667054

Joshi, A., Liao, H., \& Jackson, S. E. (2006). Cross-level effects of workplace diversity on sale performance and pay. Academy of Management Journal, 49, 459-481. http://dx.doi.org/10.5465/AMJ.2006.21794664

Kamdar, D., McAllister, D. J., \& Turban, D. B. (2006). All in a day's work: How follower individual differences and justice perceptions predict OCB role definitions and behavior. Journal of Applied Psychology, 91, 841-855. http://dx.doi.org/10.1037/0021-9010.91.4.841

Kearney, E., Gebert, D., \& Voelpel, S. C. (2009). When and how diversity benefits teams: The importance of team members' need for cognition. Academy of Management Journal, 52, 581-598. http://dx.doi.org/10.5465/AMJ.2009.41331431

Kristof-Brown, A., Barrick, M. R., \& Stevens, C. K. (2005). When opposites attract: A multi-sample demonstration of complementary person-team fit on extraversion. Journal of Personality, 73, 935-957. http://dx.doi.org/10.1111/j.1467-6494.2005.00334.x

Lau, D. C., \& Murnighan, K. (2005). Interactions with groups and subgroups: The effects of demographic faultlines. Academy of Management Journal, 48, 645-659. http://dx.doi.org/10.5465/AMJ.2005.17843943

Losoya, S. H., \& Eisenberg, N. (2001). Affective empathy. In J.A. Hall \& F. J. Bernieri (Eds.), Theory and measurement (pp. 21-43). Mahwah, NJ: Lawrence Erlbaum Associates Publishers.

McKay, P. F., Avery, D. R., \& Morris, M. A. (2008). Mean racial-ethnic differences in employee sales performance: The moderating role of diversity climate. Personnel Psychology, 61, 349-374. http://dx.doi.org/10.1111/j.1744-6570.2008.00116.x

McLeod, P. L., Lobel, S. A., \& Cox, T. H. (1996). Ethnic diversity and creativity in small groups. Small Group Research, 27, 248-264. http://dx.doi.org/10.1177/1046496496272003

Milton, L. P., \& Westphal, J. D. (2005). Identity confirmation networks and cooperation in groups. Academy of Management Journal, 48, 191-212. http://dx.doi.org/10.5465/AMJ.2005.16928393

Pacala, J. T., Boult, C., Bland, C., \& O’Brien, J. (1995). Aging game improves medical students caring for elders. Gerontology and Geriatrics Education, 15, 45-57. http://dx.doi.org/10.1016/j.jamda.2005.07.009

Pelled, L. H., Eisenhardt, K. M., \& Xin, K. R. (1999). Exploring the black box: An analysis of work group diversity, conflict, and performance. Administrative Science Quarterly, 44, 1-28. http://dx.doi.org/10.2307/2667029

Phillips, K. W., Rothbard, N. P., \& Dumas, T. L. (2009). To disclose of not to disclose? Status distance and self-disclosure in diverse environments. Academy of Management Review, 34, 710-732. http://dx.doi.org/10.5465/AMR.2009.44886051

Pinzone-Glover, H. A., Gidycz, C. A., \& Jacobs, C. D. (1998). An acquaintance rape prevention program. Psychology of Women Quarterly, 22, 605-621. http://dx.doi.org/10.1111/j.1471-6402.1998.tb00180.x

Roberge, M. É. (2009). When and how does diversity increase group performance?: a theoretical model followed by an experimental study. VCM Publisher.

Roberge, M. É., Lewicki, R. J., Hietapelto, A., Abdyldaeva, A. (2011). Theory to practices: Recommending Supportive Diversity Practices. Journal of Diversity Management, 6(2), 1-20. http://dx.doi.org/10.1016/j.hrmr.2009.09.002

Roberge, M. É., \& Van Dick, R. J. (2010). Recognizing the benefits of diversity: When and how does diversity increase group performance. Human Resource Management Review, 20(4), 295-308. 
http://dx.doi.org/10.1016/j.hrmr.2009.09.002

Reiter-Palmon, R., Wiener, R. L., Ashley, G., Winter, R. J., Smith, R. M. Richter, E. M., \& Voss-Humke, A. (2008). The effects of empathy on judgments of sexual harassment complaints. Research on Emotion in Organizations, 4, 285-310. http://dx.doi.org/10.1016/S1746-9791(08)04013-3

Sandelands, L. E., \& Clair, L. L. St. (1993). Toward an empirical concept of group. Journal for the Theory of Social Behavior, 23, 423-458. http://dx.doi.org/10.1111/j.1468-5914.1993.tb00543.x

Settoon, R. P., \& Mossholder, K, W. (2002). Relationship quality and relationship context as antecedents of person- and task focused interpersonal citizenship behavior. Journal of Applied Psychololgy, 87, 255-267. http://dx.doi.org/10.1037/0021-9010.87.2.255

Schwartz, S. H. (1992). Universals in the context and structure of values: Theoretical advances and empirical tests in 20 countries. In M. Zanna (Ed.), Advances in experimental social psychology (pp. 1-65). Orlando, FL: Academic Press.

Shore, L. M., Chung-Herrera, B. G., Dean, M. A., Ehrhart, K. H., Jung, D. I., Randel, A. E., \& Singh, G. (2009). Diversity in organizations: Where are we now and where are we going? Human Resource Management Review, 19, 117-123. http://dx.doi.org/10.1016/j.hrmr.2008.10.004

Smith, K. K., \& Crandell, S. D. (1984). Exploring collective emotion. American Behavioral Science, 27, 813-828. http://dx.doi.org/10.1177/000276484027006011

Stegmann. S., Roberge, M. É., \& van Dick, R. (2012). Getting tuned in to those who are different: The role of empathy as mediator between diversity and performance, Zeitschrift für Betriebswirtschaft. Journal of Business Economics, Special Issue 2, 19-44 . http://dx.doi.org/10.1007/s11573-011-0543-y

Stephan, W. G., \& Finlay, K. (1999).The role of empathy in improving intergroup relations. Journal of Social Issues, 55, 729-743. http://dx.doi.org/10.1111/0022-4537.00144

Stürmer, S., Snyder, M., Kropp, A., \& Siem, B. (2006). Empathy-motivated helping: The moderating role of group membership. Personality and Social Psychological Bulletin, 32(7), 943-956. http://dx.doi.org/10.1177/0146167206287363

Tajfel, H., \& Turner, J. C. (1986). The social identity theory of intergroup behavior. In S. Worchel, \& W.G. Austin (Eds.), Psychology of intergroup relations (pp. 7-24). Chicago: Nelson.

Triandis, H. C., Kurowski, L. L., \& Gelfand, M. J. (1994). Workplace diversity. In Trandis, M. D. Dunnette, L. M. Hough (Eds.), Handbook of Industrial and_Organizational Psychology and Social Psychology (Vol. 4, pp. 769-827). Palo Alto, CA: Consulting Psychologists Press.

Turner, J. C., Hogg, M. A., Oakes, P. J., Reicher, S. D., \& Wetherell, M. S. (1987). Rediscovering the social group. Oxford: Blackwell.

Van Dick, R., Van Knippenberg, D., Hägele, S., Guillaume, Y. R. F., \& Brodbeck, F. (2008). Group diversity and group identification: The moderating role of diversity beliefs. Human Relations, 61, 1463-1492. http://dx.doi.org/10.1177/0018726708095711

Van Knippenberg, D., De Dreu, C. K. W., \& Homan, A. C. (2004). Work group diversity and group performance: An integrative model and research agenda. Journal of Applied Psychology, 89, 1008-1022. http://dx.doi.org/10.1037/0021-9010.89.6.1008

Van Knippenberg, D., \& Schippers, M. C. (2007). Work group diversity. Annual Review of Psychology, 58, 515-154. http://dx.doi.org/10.1146/annurev.psych.58.110405.085546

van der Vegt, G. S., \& Bunderson, J. S. (2005). Learning and performance in multidisciplinary teams: The importance of collective team identification. Academy of Management Journal, 48, 532-547. http://dx.doi.org/10.5465/AMJ.2005.17407918

Wanous, J. P., \& Youtz, M. A. (1986). Solution diversity and the quality of group decisions. The Academy of Management Journal, 29, 149-159. http://dx.doi.org/10.2307/255866

Webber, S. S., \& Donahue, L. M. (2001). Impact of highly and less job-related diversity on work group cohesion and performance: A meta-analysis. Journal of Management, 27, 141-162. http://dx.doi.org/10.1177/014920630102700202

Williams, K., \& O’Reilly, C. A. (1998). Demography and diversity: A review of 40 years of research. In B. Staw and R. Sutton (Eds.), Research in organizational behavior (pp. 77-140). Greenwich, CT: JAI Press. 